\title{
DEVELOPMENT OF SOCIAL EMOTIONAL LEARNING
}

\author{
Rozi Sastra Purna ${ }^{1}$ Nurmina $^{2}$ \\ ${ }^{1}$ Study Program of Psychology, Faculty of Medicine, Andalas Universityand Doctoral Student, State \\ University of Malang, $\bowtie$ rozisastrapurna@yahoo.com \\ ${ }^{2}$ Study Program of Psychology, State University of Padang.
}

\begin{abstract}
Social interactions that occur through the media make students' social interactions in the real world weakened. Students become less competent on social-emotionally, even this problem affects their academic performance. Moreover, social and emotional competence is quite important for students. Research shows that mastering of social-emotional competency is related to the better improvement of the school welfare and its performance. While failure to achieve competence in this field can lead to various personal, social, and academic difficulties. The aim of this article is viewing about Social Emotional Learning (SEL). Social Emotional Learning (SEL) is an approach that can be used by the teachers to improve the success of students in the school and their life.The usage of technology can be an alternative on approaching of social emotional Learning (SEL). The technology provides many conveniences, as well as a new way of transferring knowledge in the schools.Each innovation is created to provide positive benefits for human life, including in the teaching and learning process in the schools.Actually, many countries in the world have started developing SEL in their schools. However, there are still few countries who use technology media as the part of the SEL program.The technology that is developing at this time can be used as a learning medium to develop social emotional learning in the schools. Schools as the place for teaching and learning process must be able to utilize media technology as a teaching aid. Activities those are supported by a set of digital tools can guide them through a series of structured tasks which are designed to encourage the students' understanding of culture, the guide interaction, the problem solving and decision making about the social and emotional issues.The learning tools for SEL development can be in the form of digital stories and animations, as well as the discussions with the online instruction guides.
\end{abstract}

Keywords:Social Emotional Learning (SEL), Media, Technology.

\section{Introduction}

The childhood times should have experienced growth by socializing themselves which is shown by starting to establish a relationship of social interaction with the surrounding environment of themselves. At that moment the children have been able to demonstrate prosocial behavior such as 
sharing and helping (Eisenberg, Fabes \& Spinrad, 2006).However, based on the observations in the kindergarten, there are still many children who have not demonstrated prosocial behavior such as helping a fallen friend, helping the friends who are having trouble working on the tasks, sharing food with the friends who do not bring a food, lending the toys, cheering up the friends who cry and working together to clean up toys, there are even children who are reluctant to interact and tend to be aggressive.

On the other hand, the development of information and communication technology has been so fast that it has unwittingly affected every aspect of the children's lives. Increasing use of technology actually decreases the intensity of the individual relationships. According to Ameliola \& Nugraha (2013) The social interactions that occur through the media make society's social solidarity ties weaken. Consequently, the students become less social-emotionally competent, even affect their academic performance (Blum \& Libbey, 2004).

Another challenge in this century is the increasingly the diversity of ethnicity, religion and culture in one school. So, it is needed the ability to interact socially. Social competence can be interpreted as the socially acceptable, as well as ways of learning behavior that enable a person to interact effectively with the others, and also lead to behaviors and social responses that are owned by the individuals. Some examples of the behavior are sharing, helping, working together, having an initiative towards a relationship with the others, having a sensitivity to the others, and handling the problems with the good situations (Gresham \& Elliot, 1990).

This social emotional skill cannot just happen as that way, but requires a process to make it happen which starts from the emotional social formation in the environment, including in the school environment either. People who are skillfully trained emotionally, then he/she will be more skilled at solving his/her own problems, he/she can control the negative ideas in any conditions and can also accept what the other friends want. Social emotional learning is the process by which the students learn to recognize and manage the emotions, caring to others, making good decisions, behaving ethically and responsibly, and developing the positive relationships, also avoiding the negative behaviors (Elias et al., 1997). The process can involve the technology such as the use of multimedia computers, the internet and the other audio-visual facilities as the learning media. Usually students are always interested in new things about technology. Therefore, the development of social emotional techniques can be obtained by utilizing the technology in learning (Abdulhak \& Darmawan 2013). Therefore, the school as a place for teaching and learning process must be able to utilize the technology media as a teaching tool and this article aims to review theories and research on emotional social learning and the use of technology as a learning medium.

Urgency of Social and emotional learning (SEL)

Social and emotional learning (SEL) is a promising approach to increase the success of students in the school and life (Elias, et al. 2006). Research shows that mastery of social-emotional competencies is related to the better school welfare and its performance while failure to achieve competence in this field can lead to the various personal, social and academic difficulties (Eisenberg, 2006).

Recent research has found the fact that the students who develop social and emotional competencies can lead healthier lives and have better performance in the schools (Greenberg, et al., 2003). Therefore, the educators and governments around the world promote learning that emphasizes social and emotional skills (SEL) (Durlak, et al, 2011).The Wong's research, et al (2014) states that $62.96 \%$ of participants who have lower social knowledge have many behavioral problems. Therefore, Wong tried a social emotional learning program to overcome it.As a result, the treated group experienced social knowledge progress after completing the program. Even though, the results do not show very high significance. For the frequency of behavior problems, the treated group was 
experiencing reduction after the program. Marcom (2015) stated the same thing, where social emotional Learning programs can reduce bullying behavior in the schools.Responding to this concern, the media elements of the information technology can be used as an alternative to facilitate the learning process and increase the students' attention to the lesson. Usually students are always interested in the new things and the technology. Therefore, the social emotional development can be used by utilizing technology in learning (Abdulhak \& Darmawan 2013).

\section{SEL in the various countries}

The SEL program is widely applied in various countries such as America, Europe and Australia. Research in Australia using the program of You Can Do It! Early Childhood Education has been proven effective in improving the students' social and emotional competencies. This is consistent with the previous research which says that the YCDI program is an effective way to teach the social and emotional skills. The results of the study that was conducted by Collie, et al. (2011) in Australia show that YCDI program is effective also for the students from the various cultural backgrounds. This program is also effective for male and female students.

Development of the SEL modules in Hong Kong those were conducted by Chi-Ming Kam, et al (2011) which refers to the PATHS Program that was developed by Greenberg and Kusche. (Greenberg \& Kusche 1993). This SEL program is the school-based that promotes emotional understanding, emotional regulation and problem solving skills. The PATHS model refers to the basic development research and focuses on interpersonal problems that have a major influence on students' social behavior.If the students misidentify their own feelings or others, they tend to produce the maladaptive solutions on the problems in their lives. In addition, the motivation of students in communicating and taking the problem solving will be greatly influenced by the modeling and strengthening of adults and their peers.

The PATHS designs are based on $\mathrm{ABCD}$ acronyms (affective, behavioral, cognitive, dynamic) (Greenberg \& Kusche 1993), which places a major interest in the integration between the development, behavior, and cognitive understanding which are related to the social and emotional competence. The PATHS model synthesizes the domain of the self-control, emotional awareness and understanding, as well as the social problem solving to improve the social and emotional competence.In the United States of America, the SEL-RULER module is designed to improve the quality of the classroom interaction through the professional development and the classroom curriculum that instills the emotional skills instruction in teaching and learning interactions. RULER is a universal SEL program that targets five key emotional skills based on the model of achieving emotional intelligence. These skills include recognizing the emotions of yourself and the others, understanding the causes and effects of the emotions, labeling emotions accurately and in various vocabulary, also expressing and regulating/managing emotions in a socially appropriate way (Hagelskamp, et al, 2013).

\section{Theoretical and Discussion}

The development of information technology has influenced the world of education, especially in the learning process. According to Rosenberg (2001), with the development of the use of technology and information, there are 5 (five) shifts in the learning process, namely: (1) from the training to the appearance, (2) from the classrooms to anywhere and anytime, (3) from the paper to "online" or the channel, (4) from the physical facilities to the network facilities, (5) from the cycle time to the real time.

Communication as an educational media can be done using media such as computers, internet, e-mail, and others. The interaction between teacher and students is not only done through 
the face-to-face contact but also by using these media. The students can obtain information in a wide scope from the various sources through the cyber or virtual space by using the computers or the internet.

The children are dealing with the computers and the interactively learning activities through the internet to obtain learning materials from various learning sources. The curriculum is developed in such a way that considers the conditions of the environment and the conditions of the children. So, it can provide the opportunities for the learning process.

The specification of the SEL learning support through the technology media is a Social emotional Learning (SEL) guide or module that is in the form of a SEL guide that contains material related to 1) self-awareness; recognize feelings (consciousness) because they are in the real life situations; 2) managing emotions; to regulate/manage emotions with the strong feelings so that they are not overwhelmed and either carried away by the emotions, 3) self-motivation; self-motivation that is a goal-oriented and able to transfer the emotions towards the desired results, 4) empathy and perspective-taking; to empathize and recognize the emotions also to understand the other people's perspectives, 5) social skills, the ability to maintain the relationships in a social environment.

To be able to utilize the technology and information media for improving the quality of learning, there are three things that must be realized, namely: (1) the students and teachers must have access to the digital technology and the internet in the classes, schools, and teacher education institutions, (2) there must be available quality material, meaningful, with cultural support for students and teachers, and (3) teachers must have the knowledge and skills in using digital tools and resources tools to help the students for achieving the goals of academic standards.

The technology is used as a learning medium. Every innovation is created to provide the positive benefits for human life. Provides many conveniences, as well as a new way of transferring knowledge in the schools. Media is defined as the product of technology-mediated communication that is shared with the digital computers. Learning with the technology and information media is used as a tool to facilitate learning to be more enjoyable, and can also be used as a development of children's social emotional functions. Children usually play games with the information media and technology that have been prepared by the teachers that can be played in the form of power points, winamp (music application/software), and laptops. SEL's focus is through the Peer Group. According to Elias (1997) information from the playmates and adult students can shape the student behavior itself. the SEL application model that uses references to the peer group models and the website-based electronic media (Iaosanurak et al. 2015).Each stage of the learning activities is designed to encourage the cross-cultural understanding, student interaction in the dialogue, the problem solving and decision making about social and also the emotional issues. The activities that are supported by a set of digital tools and which guide them through a series of structured tasks. The learning tools for the SEL development include the digital animation stories, discussion groups with the six questions, the forms / templates and handbooks.

Besides of using the peer group method, the implementation process also uses the electronic media website-based. In Iaosanurak research, et al (2015) digital animated stories were created as the stimuli by using the software Macromedia Flash and Adobe Photoshop. Research from Iaosanurak, et al. (2015) spent 7 to 15 weeks intervening. Instructions in the computer media are designed to guide students to reflect, interact, make decisions, and to solve the problems and dialogue.Each group answer in a mind map program is a collaboration between individual students through the online discussion forums. Students will be involved in the blocks of learning activities that have been compiled in the online program that has been created.The activity takes place in a computer laboratory with one computer for one group. Each group sees a digital animated story on a computer. After seeing the story, the students collaboratively and interactively discuss and answer the six questions given to them in the media provided. 


\section{Conclusions}

Social and emotional learning (SEL) is a promising approach for increasing the success of the students in the school and in their lives. SEL is a process where we learn to recognize and manage emotions, care about others, make good decisions, behave ethically and responsibly, and develop positive relationships, and also avoid negative behavior. The technology media is used to develop SEL components, they are: self awareness, self management, responsible decision making, social awareness, and relationship skills, as well as the development of expertise components.

The school as a place for learning and teaching process should be able to take advantage of technological media as the learning tools that is used by the teachers. The use of technology is a process that can increase added value, where the products used and produced can facilitate and improve the human performance. Each innovation is created to provide the positive benefits for the human life, including in the teaching and learning process in the schools. Technology provides many conveniences, as well as a new way of transferring knowledge in the schools.

The information technology can be directed to include the matters which are related to the emotional awareness, self-control, interpersonal problem solving, and peer relationships. Each stage of learning activities is designed to encourage cross-cultural understanding, student interaction in dialogue, problem solving and decision making about the social and emotional issues. Includes the activities that are supported by a set of digital tools and can guide them through a series of structured tasks. Learning tools for developing SEL can be in the form of digital stories or animations and the process of student discussion using the online instruction guides in accordance with the current technological sophistication.

\section{References}

Abdulhak, I. \& Darmawan. (2013). Teknologi Pendidikan. Bandung: PTRemaja Rosdakarya.

Association for Supervision and Curriculum Development. (2007). The learning compact redefined: A call to action-A report of the Commission on the Whole Child. Alexandria, VA: Author.

Ameliola, S dan Nugraha, D.H. (2013). Perkembangan Media Informasi dan Teknologi Terhadap anak dalam Era Global. Prosiding the 5th international conference on Indonesian studies: Ethnicity dan Globalitation.

Blum, R. W., \& Libbey, H. P. (2004). School connectedness Strengthening health and education outcomes for teenagers. Journal of School Health, 74, 229-299.

Collie, R. J., Jennifer D. S., \& Nancy E. P. (2011). Predicting teacher commitment: the impact of school climate And social-emotional learning. Psychology in the schools. Vol. 48 (10), 1034-1048

Durlak, J.A., Roger P. W., Allison B. D., Rebecca D. T, Kriston B. S. (2011). The Impact of Enhancing Students' Social and Emotional Learning: A Meta-Analysis of School-Based Universal Interventions. Child Development. 82, $405-432$

Eisenberg, N., Fabes, R.A., \& Spinrad, T. (2006). Prosocial Development. In N. Eisenberg (Vol. Ed.), W. Damon \& R.M. Lerner (Series Eds.). Handbook of child psychology: Vol. 3. Social, emotional and personality development (6 th ed., pp. 646-718). New Jersey: John Willey \& Sons, Inc. 
Elias, M. J., Zins, J. E., Weissberg, R, P., Frey, K. S., Greenberg, M. T., Haynes, N. M., Kessler, R., Schwab-Stone, M. E., \& Shriver, T. P. (1997). Promoting social and emotional learning, Alexandria, VA: Association for Supervision and Curriculum Development.

Elias, M. J., Zins, J.E. Weissberg, R. P. at al. (1997). Promoting Social and Emotional Learning: Guidelines for educators. Alexandria VA: Association for supervision and curriculum development.

Elias, M. J., \& Weissberg, R. P. (2000). Primary prevention: Educational approaches to enhance social and emotional learning. Journal of School Health, 70 (5), 186-190.

Elias, Maurice J., Joseph E. Zins, Roger P. Weissberg, Karin S. Frey, Mark T. Greenberg, Norris M. Haynes, Rachael kessler, Mary E. Schwab-stone, Timothy P. Shriver. (1997). Promoting Social and Emotional Learning : Guidelines for Educator. USA: the Association for Supervision and Curriculum Development.

Elias, M. J. \& Schwab, Y. (2006). From compliance to responsibility: social and emotional learning and classroom management. Dalam C. Evertson \& C. S. Weinstein (Eds.) Handbook for classroom management: Research, practice and contemporary isues, Mahwah, NJ: Lawrence Erlbaum.

Gresham, F.M \& Elliot S.N. (1990). Social Skill Rating System Manual. Circle Pines, MI. American Guidance System.

Goleman, D. (2001). Emotional Inteligences : Kecerdasan Emosional,Mengapa EL Lebih Penting Daripada IQ. PT.Gramedia: Jakarta.

Goleman, D., (2001). Kecerdasan Emosional. Jakarta : Gramedia Pustaka Raya

Goleman, D., (2004). Emotional Intelligence; Kecerdasan Emosional Mengapa Lebih Penting dari IQ. Jakarta : Gramedia Pustaka Utama

Greenberg, M. T., Weissberg, R. P., O’Brien, M. U., Zins, J. E., Fredericks, L., Resnik, H., et al. (2003). Enhancing Social and Emotional Learning school-based prevention and youth development through coordinated social, emotional, and academic learning. American Psychologist, 58, $466-474$.

Gresham, F.M \& Elliot S.N. (1990). Social Skill Rating System Manual. Circle Pines, MI. American Guidance System.

Hagelskamp C., Marc A. B., Susan E. R., \& Peter S. (2013). Improving classroom quality with the RULER approach to social and emotional learning: proximal and distal outcomes. Springer: Original Paper Am J Community Psychol. Vol. 51, 530-543

Hartup, W. W. (1992). Having Friends, Making Friends, and Keeping Friends. ERIC Digest. Urbana IL: ERIC Clearinghouse on Elementary and Early Childhood Education.

Iaosanurak, C., Chanchalor S. \& Elizabeth M. (2015). Social and emotional learning around technology in a cross-cultural, elementary classroom. Educ Inf Technol DOI 10.1007/s10639015-9406-4

Joseph A. Durlak, Roger P. Weissberg, Allison B. Dymnicki, Rebecca D. Taylor, Kriston B. Schellinger. (2011). The Impact of Enhancing Students' Social and Emotional Learning: A Meta-Analysis of School-Based Universal Interventions. Child Development. 82, 405 - 432

Kam, C.M., Lance W. W., Kennis M. F. (2011). Promoting social-emotional learning in Chinese schools: A feasibility study of PATHS implementation in Hong Kong. The International Journal Emotional Education. Volume 3, Number 1, April 2011 pp 30-47

Learning First Alliance. (2001). Every child learning: Safe and supportive schools. Washington, DC: Author.

Morcom V. (2015). Scaffolding social and emotional learning within shared affective spaces' to reduce bullying: a sociocultural perspective. Elsevier: Culture and Social Interaction. Vol. 6, 77-86

Mertens, Nina. (2010). Social Competence in Bullies, Defenders and Neutrals: A Comparison. Bachelor Thesis. Utrecht University. 
Pellegrini, A. D. \& Glickman, Carl D. (1991). Measuring Kindergartners' Social Competence. ERIC Digest.

Payton, J. W., et al. (2000). Social and emotional learning: A framework for promoting mental health and reducting risk behavior and children and youth. Journal of school health 7-, 179-185

Weisinger, Hendrie. (1998). Emotional Intelligence at Work: The untapped Edge for Success. San Franscisco: Jossey-Bass Inc.

Woolfolk, A. (2009). Education Psychology Active Learning Edition. Yogyakarta : Pustaka Pelajar.

Wong, A.S. K., Cecilia W.P. Li-Tsang, Andrew M.H. Siu. (2014). Effect of a Social Emotional Learning Programme for Primary School Students. Elsevier: Hong Kong Journal of Occupational Therapy. 24, 56-63

Zins J E, dkk .(2004). Building Academic Succes On Social And Emotional Learning. New York: Teachers College Press.

Zins, Joseph E., Roger P. Weissberg, Margaret C. Wang, and Herbert J. Walberg, (2001), Building Academic Success on Social and Emotional Learning: What Does the Research Say?, New York: Teachers College Press 